\title{
Brave women sound the alarm - representations of men and women in the Swedish media coverage of \#MeToo
}

\author{
LISA LINDQVIST \\ Karlstad University \\ HILLEVI GANETZ \\ Stockholm University
}

\section{Abstract}

In the autumn 2017 in Sweden, the \#MeToo movement and sexual assault became a focus of broad debate. Swedish media coverage of the movement was centred around the many petitions made by anonymous groups of women to illuminate the extent of the problem of sexual assault, as well as a few cases of accusations against wellknown and powerful men in both the culture and media industries. In order to elicit common representations of men and their female accusers, this study applies critical discourse analysis (CDA) to news media coverage and Facebook comments of three of those accused men: TV personality Martin Timell, journalist Fredrik Virtanen and culture personality Jean-Claude Arnault. The results indicate that representations of women as both witnesses and heroines work to reinforce notions of female responsibility as a means to halt sexual assault, while representations of men as sexual predators build on demarcations of illegal and mere misogynistic or "bad" behaviour, which in turn reinforce notions of male victimhood. These representations point to legal discourse as hegemonic, as it seems to limit the discussion and only present individual solutions, such as women bearing witness, to the structural problem of sexual assault. Simultaneously, the results indicate that the \#MeToo movement and other 
feminist discourse have also had an effect on news media representations of sexual assault by broadening the concept beyond the consent/rape dichotomy.

\section{KEYWORDS}

\#MeToo, Sweden, media, discourse analysis, representations, sexual harassment

\section{Introduction}

In 2017, fuelled by the many allegations of sexual assault against Hollywood producer Harvey Weinstein, the \#MeToo hashtag grew into a movement. In October of that year, the \#MeToo movement gained momentum from a Twitter post by actress Alyssa Milano who called on all women who had been victims of sexual assault or harassment to reply to her tweet with the words 'me too'. Originally coined in 2006 on Myspace by women's rights activist Tarana Burke, by the autumn of 2017, the 'MeToo' phrase erupted into an extensive social movement in many countries. In Sweden, the \#MeToo movement led to a wide range of public reactions, as well as ignited extensive news media coverage. Street protests were organised, many women took to social media to tell their own stories and several leading politicians, including the Prime Minister, showed their support for the movement. From a vast array of different industries, women came together to talk anonymously about their experiences of sexual assault in the workplace, resulting in over 70 petitions (including various calls for action on social media and debate articles published in the news media) and the birth of new \#MeToo-related hashtags including \#tystnadtagning, \#medvilkenrätt, \#deadline, \#imaktenskorridorer and \#tystiklassen (by actors, lawyers, journalists, politicians and teachers, respectively). In July 2018, the Swedish law on sex crime was changed to include an affirmative consent clause. The Swedish media coverage of the \#MeToo movement included the aforementioned petitions as well as stories of individual accusations against powerful men within both the media and cultural sectors. 
In October 2017, only a few days after the New York Times first published the accusations of Harvey Weinstein, the Swedish former TV show host Lulu Carter published a post to Instagram likening the Hollywood producer to a former colleague of hers, TV personality Martin Timell. Two days later, Alyssa Milano's tweet would inspire thousands of women to tell their stories, one of whom was Swedish journalist and activist Cissi Wallin. In a post on Instagram, she named journalist Fredrik Virtanen as her rapist, alluding to an assault that took place in 2006. The two stories were picked up by Swedish news media, which described further female accusations against the men as well as their individual explanations and denials. On 21 November 2017, the major Swedish newspaper Dagens Nyheter published an extensive investigation into a powerful, semi-public figure within the cultural sphere, Jean-Claude Arnault, otherwise known in Swedish as "Kulturprofilen" (the Culture Personality). According to the news article, Arnault had allegedly sexually assaulted a considerable number of women, 18 of whom were interviewed individually by journalist Matilda Gustavsson. Arnault was subsequently named in the media and due to his close personal ties to the Swedish Academy (his wife is a member), the 2018 Nobel Prize in Literature was soon thereafter postponed.

This study uses critical discourse analysis (CDA) to analyse news media articles, op-eds and Facebook comments concerning the three men: Arnault, Timell and Virtanen. The study's aim is to elicit overarching themes and subject positions in order to identify possibilities and limitations in the news media and audience discourse in regard to both sexual assault and its relationship to the \#MeToo movement and dominant discourse on sexuality.

\section{The following research questions were used:}

1. How are the men and their behaviour represented and explained in news media articles, opinion pieces and Facebook comments?

2. How are the women and their behaviour represented and explained in news media articles, opinion pieces and Facebook comments? 


\section{Previous research and theoretical background}

Using discourse theory as a point of departure, this study builds on previous research regarding both media representations of rape and the possibilities of hashtag movements.

\section{Media coverage of sex crime: Rape myths and counter-discourse}

The idea guiding research on media representations of sex crime is that the representations have an effect on audience perception of the typical rapist, the behaviour of a rape victim and the cause of sex crime (Worthington 2008, Hamlin 1988, Johnson 1999, Franiuk, Seefelt \& Vandello 2008). Jody Freeman (1993) and Marian Meyers (1997) claim sex crime stereotypes are circulated back and forth throughout societal institutions via the media as they pick up stories from public debate, the justice system and interviewed police officers. In media research, these stereotypes are often referred to as "rape myths", as they limit the notion of what a "real" rape is. Several researchers claim rape myths result from a view of the world as controllable and fair, which may be unwillingly subscribed to by journalists, media producers and the media audience (Franiuk et al., 2008, ArdoviniBrooker \& Caringella-Macdonald 2002). With this unconscious worldview, only "bad" men commit rape and only "bad" women (behaving in socially unacceptable ways) are rape victims. Moreover, in these terms, only an assault in a public place by a stranger is considered "real rape" (ibid, Meyers 1997, Hinck \& Thomas 1999).

At the same time, several researchers believe that feminist movements, public debate and changes in legislation on sex crime have all had an impact on news media representation of rape, dating back as early as the 1980s (Ardovini-Brooker \& Caringella-Macdonald, 2002, Lós \& Chamard 1997, Serisier 2017). These researchers claim that this has resulted in a widening of the concept of rape to include attacks carried out not only by "psychopathic strangers" but also by acquaintances. Furthermore, the researchers describe how a feminist impact on media representations of rape seems to have resulted in a shift towards focusing on the point of view of the victim. However, during the same time period, research also points to the prevalence and reinforcement of rape myths (ibid.). 
In today's media landscape, representations of rape are, more so than before, a result of several actors writing about, interpreting, discussing and questioning the incident. Nancy Worthington (2008) describes this as an ongoing struggle by media producers and consumers alike for hegemony within the discourse on sex crime. She claims that universal access to social media networking sites, blogs, etc., suggests that the position of power is no longer solely reserved for traditional media producers, which in turn opens up possibilities for resistance and subversion (ibid). Simultaneously, research by Jemma Tosh (2016) and Emily Thomas, Michelle Lafrance, and Monika Stelzl (2018), which looks into social media discussions on sexual assault, identifies a need for an expanded debate. Tosh and Thomas, Lafrance and Stelzl claim the discussion needs to move away from the consent/rape dichotomy and towards more nuanced ways of talking about negative sexual experiences.

\section{Possibilities and limitations of hashtag movements}

The \#MeToo movement may be described as shifting the media discussion on sex crime in this suggested direction - that of creating more nuanced ways of discussing negative sexual experiences. Rosalind Gill and Shani Orgad (2018) suggest that much of the success of the movement has to do with the heterogeneity of the stories brought forward within it, creating a collective spirit and a worldwide spread. This theory supports earlier research describing feminist hashtag movements as effective ways of creating counter-discourse by linking together large quantities of personal stories (Clark 2016, Barker-Plummer \& Barker-Plummer 2017). According to Rosemary Clark (2016), feminist hashtag movements typically result in more accurate media reports on sex crime while at the same time producing gendered solidarity.

Although the \#MeToo movement seems successful in this regard (Modrek \& Chakalov 2019, Schneider \& Carpenter 2020, McDonald 2019), several researchers suggest that as it makes the problem with sexual assault relatable and easy to understand, \#MeToo also risks oversimplifying complex issues. One such risk is individualisation of the problem of sexual assault by reinforcing neoliberal ideas of female sexuality, such as responsibility for conveying consent (McDonald 2019, Modrek \& Chakalov 2019, Gill \& Orgad 2018, 
Worthington 2020). Considering readers' reactions to an op-ed piece about sexual assault accusations against comedian Aziz Ansari, Worthington (2020) notes that the more popular (upvoted or liked) comments reinforced neoliberal notions of individual responsibility. However, she did find that some comments emphasised rape culture as a structural problem. Thus, hashtag movements such as \#MeToo can create counter-discourse from linking together large numbers of personal stories, but might risk oversimplification of structural problems that in turn reinforce hegemonic neoliberal ideas. At the same time, hashtag movements provide opportunities for counterdiscourse that can encourage structural change to emerge and possibly make its way into the media discourse on sex crime.

\section{The \#MeToo movement in the media}

In Sweden, the \#MeToo movement was successful in creating an extensive media discussion that spread to the political world and the public debate. Tina Askanius and Jannie Møller Hartley (2019) suggest that the movement had a larger impact in Sweden than in Denmark; many media entries were positive towards the movement and critical towards patriarchal culture. Although Askanius and Hartley found that \#MeToo news media coverage predominantly framed sexual assault as an individual rather than a societal problem in both countries, Swedish media used a frame of understanding sex crime as a structural problem more often than Danish media (ibid). The same can be said for UK news coverage of \#MeToo, according to Sara De Benedictis, Shani Orgad and Catherine Rottenberg (2019). They claim that the UK reporting did show support for, and expanded the reach of, the movement. However, they also suggest that British news coverage focused largely on individual celebrities and failed to discuss potential solutions to the problem of sexual assault other than "empowering women to speak out" (ibid: 15). This suggests that the Swedish media coverage of the \#MeToo movement employ a frame representing sex crime as a structural and societal problem, more so than the Danish and British coverage. 


\section{Discourse theory: Hegemony and subject positions}

The study uses discourse theory as a point of departure, focusing mainly on the concepts of hegemony and subject positions. We draw on both discourse theory developed by Ernesto Laclau and Chantal Mouffe (1985) and critical discourse analysis as defined by Lilie Chouliaraki and Norman Fairclough (1999). These two theories depart from a view of the social world as socially constructed and language as an important constituent. Discourse is language structured in social practice, linguistic elements articulated together and dialectically related to other social practices and the social world as a whole (Laclau \& Mouffe 1985, Chouliaraki \& Fairclough 1999). Since discourse is related to the social world in this way, these theories point to discourse being both a creative resource and a limiting power. This makes discourse theory useful in this study since it aims to understand possibilities and limitations of the \#MeToo movement in relation to dominant discourse on sexuality and sexual assault.

Hegemony is a concept used to explain this limiting property of discourse and its connection to ideology. When some discourses seem more true, neutral and objective than others, they have a hegemonic stance. This relates to ideology in that the above-mentioned discourses both limit the possibilities of interaction and uphold relations of power, which in turn shapes discourse and naturalises some discourses over others (Laclau \& Mouffe 1985, Chouliaraki \& Fairclough 1999).

As discourse is seen as an important constituent of the social world, it is also related to identity. Social identities are produced in discourse (Laclau \& Mouffe 1985). These socially constructed, linguistic identities are referred to as subject positions in this analysis, meaning flexible discursive resources drawn on by social actors. Subject positions are, in this way, both limiting and creative possibilities that relate to power and ideology. Hegemonic discourse produces a limited repertoire of social positions available to social actors and, as other discursive elements, these positions derive meaning from their relations to each other (Laclau and Mouffe 1985). In this study, the concepts of hegemony and subject positions are used as tools to understand how some explanations and interpretations of sexual acts might appear truer than others due to expectations tied to social identities. 


\section{Feminist movements and institutionalised injustice}

As this study explores the possibilities and limitations of a modern feminist hashtag movement by analysing news media coverage of \#MeToo and its audience reactions, we suggest an analytical approach inspired by the critique against modern day leftist and feminist movements put forward by, among others, Nancy Fraser (2003). She describes the justice claims of such movements as too focused on the social/cultural dimension, which she refers to as recognition and explains as cultural and symbolic deconstruction. Fraser proposes that this is related to the hegemony of a neoliberal view of social justice and that these movements need instead to focus on both recognition and economic redistribution, as well as representation - a dimension of injustice concerned with who gets to be included in society's justice concepts (Fraser 2005, 2011). This threedimensional model of justice is needed, Fraser states, to eliminate injustice from all social arenas where it has been institutionalised.

This is in line with Laclau and Mouffe's (1985) claim that the gender system is a consequence of the institutionalisation of discursive constructions of two distinct sexes and traits belonging to them. Femininity has been constructed as subordinate to masculinity on the social/cultural level, but feminist movements also have to address the fact that this value system is institutionalised, which has led to injustice on other levels (ibid.). This critical outlook on modern day feminism may assist in analysing the debate regarding \#MeToo. Hashtag movements aimed at shining light on the issue of sexual assault, as well as media coverage of such movements, have been criticised for reinforcing an oversimplified and individualised view of complex structural issues (e.g., De Benedictis, Orgad \& Rottenburg 2019, McDonald 2019, Worthington 2020).

\section{Method and material}

The study looks at a small representation of Swedish news media coverage of the \#MeToo movement and comments from its audience. Chosen for the analysis were three cases involving accusations against famous men: TV personality Martin Timell, journalist Fredrik Virtanen and culture personality Jean-Claude Arnault. All three 
of these men received large media coverage early on in the \#MeToo movement. The aim of the study is to identify possibilities and limitations of news media representations of the \#MeToo movement relative to power relations. We use critical discourse analysis (CDA) to elicit subject positions and overarching themes from news articles about the men, as well as related op-eds and Facebook comments. Thus, the study shows how discourse might work as a limiting force reinforcing asymmetric power relations (Chouliaraki \& Fairclough 1999, Winther Jørgensen \& Phillips 2000). We chose to include news articles, op-eds and Facebook comments to explore how different actors in different contexts made sense of descriptions of sexual assault and how this might be related to possibilities and limitations of the \#MeToo movement.

Since this is a qualitative study, the analysis points only to themes emerging from this particular sample of texts and makes no claims of generalisation. As the material consists of different genres, news articles, op-eds and reader comments on Facebook, the analysis was conducted in three steps, each pertaining to a different genre. The material was read through several times and notes were taken on how the women and the men, as well as their respective actions, were portrayed and discussed, and how this related to the specific context tied to each type of material. The analysis was guided by the following questions: How are the men and women referred to? How are their actions described and explained in regard to motivating factors? After analysing the different genres separately, we sought to identify any common themes and contradictions across and between the genres.

\section{Material}

The news articles and op-eds were identified using the media archive Retriever, a Nordic news media archive that gathers material from print and digital media, radio and TV. We selected only articles published in the press between October 2017 to December 2017, with one exception, as Arnault first stated his opinion (through his defence attorney) in an article published on 8 March 2018. The time period was chosen in order to capture the initial media coverage of the cases. As the men had yet to be tried for any crimes, we 
anticipated the depictions of the events in the press would be the most homogeneous during this initial moment. The names of the accused men and the epithets used for them in the media coverage were used as search terms. The number of search hits for the time period selected were 8,360, 3,077, and 20,497 for Timell, Virtanen and Arnault respectively, as shown in Table 1.

In order to narrow the sample while at the same time keeping the selection comprehensive, included were only articles from the four largest national newspapers in Sweden, the broadsheet papers Dagens Nyheter (DN) (liberal) and Svenska Dagbladet (SvD) (liberal conservative), the tabloid newspapers Aftonbladet (social democratic) and Expressen (liberal), as well as the public service media house Sveriges Television's news site SVT Nyheter. Similar articles that built on one another were grouped, and the initial version was selected for the sample. Additionally, only those texts thoroughly depicting the men accused and the women accusers, as well as the behaviour leading to the accusations, were selected. One or two texts were chosen to represent the commencement of the coverage of each case, and approximately eight texts were selected to represent responses consisting of interviews and opinion pieces. Included in the sample were eleven articles and op-eds about Timell, seven about Virtanen and ten about Arnault, coming to a total of 28 .

\begin{tabular}{|l|l|c|}
\hline Case & Search hits in media archive Retriever & Number of texts in sample \\
\hline Martin Timell & $\begin{array}{l}\text { 5,252 using the name, 3,108 using the } \\
\text { epithet "TV4-profilen" (TV4 profile) }\end{array}$ & 11 \\
\hline Fredrik Virtanen & $\begin{array}{l}\text { 2,623 using the name, 454 using the } \\
\text { epithet "Aftonbladetprofilen" } \\
\text { (Aftonbladet profile) }\end{array}$ & 7 \\
\hline Jean-Claude Arnault & $\begin{array}{l}\text { 3,335 using the name, 17,162 using } \\
\text { the epithet "Kulturprofilen" (Culture } \\
\text { profile) }\end{array}$ & 10 \\
\hline
\end{tabular}

Table 1: Number of search hits in media archive Retriever and number of texts in sample for each of the three cases.

In 2019, as Facebook was used by $74 \%$ of Swedish internet users over the age of 12 - making it the most popular social networking site in Sweden (Internetstiftelsen 2019) - we thus chose Facebook comments to represent media audience commentary. The sample includes all comments from four posts in which the selected news 
media publications shared the commencement articles on their respective official Facebook pages. Of the 380 comments, 169 came from a post about Timell by Aftonbladet (19 October 2017), 110 from a post about Virtanen by Svenska Dagbladet (25 October 2017), 52 from a post about Arnault by Dagens Nyheter (21 November 2017) and 49 from a post again about Arnault by Expressen (1 December 2017), shown in Table 2.

\begin{tabular}{|l|l|c|}
\hline Case & Facebook page and date of post & Number of comments \\
\hline Martin Timell & Aftonbladet, 19-10-2017 & 169 \\
\hline Fredrik Virtanen & Svenska Dagbladet, 25-10-2017 & 110 \\
\hline Jean-Claude Arnault & $\begin{array}{l}\text { Dagens Nyheter, 21-11-2017 and } \\
\text { Expressen 01-12-2017 }\end{array}$ & $52+49$ \\
\hline
\end{tabular}

Table 2: The Facebook entries chosen and the number of comments for each case.

In Sweden, the press adheres to the Journalistic Code of Ethics, a voluntary set of journalistic guidelines for news media. The guidelines state that news should be correct, respect personal integrity, always depict both sides of an issue, and take care when publishing names, among other things (Statens Medieråd 2020). Not following these rules might result in the Swedish Press Council (Pressens Opinionsnämnd) taking up an inquiry. This responsibility does not apply to user comments on the official Facebook pages of news media publications. However, the four publications, whose comment fields are used in the analysis, have published guidelines for commenters on their respective Facebook pages. Although the guidelines differ somewhat, they all call for users to consider their own responsibility to comply with the law and to make sure they do not insult or threat anyone, nor make racist or sexist comments, etc. (SvD 2020, Aftonbladet 2018, Expressen 2020, DN 2018). These differences in regulating principles of news texts and Facebook comments are considered in the analysis.

As the analysed material was originally written in Swedish, it has been translated by the authors. All comments from social media were anonymised prior to the analysis. They appear without editing, except for the translation. 


\section{Findings}

Firstly, it is worth noting that since the publication of the analysed material, Jean-Claude Arnault has been sentenced to 2-1/2 years in prison for two cases of rape. Martin Timell was tried in court for one case of rape but was acquitted. Fredrik Virtanen was never tried in court on the accusations of sexual assault, mainly because of the expired statute of limitations. However, he himself did sue one of his accusers, journalist Cissi Wallin, who was subsequently sentenced for defamation.

As the three cases had different developments, the media coverage of the respective cases changed and evolved differently over time. Nevertheless, this early coverage shows large similarities in how the stories broke in the press. Although varying somewhat in size and scope, the stories were initiated with reportages in which several sources accused the then anonymous men of sexual assault. In the media coverage that followed, the men were eventually named. This decision was debated in the press and following this, several articles were blamed by the Swedish Press Council (Pressens Opinionsnämnd) for breaking the Journalistic Code of Ethics. The three cases differ in the number of women coming forward with stories, and while Virtanen and Timell were interviewed by the press shortly after their stories broke, Arnault made no statements to the press at the time. The cases, however, are similar in that they portray men with power in the media and culture industries. For an extended period of time, all three men seem to have behaved in a sexually predatory way towards women while still managing to maintain privileged careers.

Analysing only the first months of press coverage and reactions from the media audience allows for identifying common themes in the media coverage of the three cases before they began to differ, as the accusations were further investigated. The results show that although the material is diverse, the subject positions for the men and women build on similar gendered notions of responsibility and victimhood. News texts, op-eds and Facebook comments are analysed respectively below, and this is followed by a concluding discussion of how the overarching themes relate to both the \#MeToo movement and dominant discourse on sexuality. 


\section{News texts: Women-as-witnesses and men-as-victims}

The reports and news articles in the material express an intertextual news genre in which principles of journalistic ethics seem to integrate with the use of legal language. The women's acts of talking to the press about their experiences of sexual assault are often times described as witnesses coming forward and making accusations. Several times in the news articles, references are made towards women's credibility, for example, by referring to the fact that multiple independent sources tell similar stories of encounters with the men, or by using quotes from other sources saying that they believe in the credibility of the stories because they know and trust the women. Thus, the news texts create an almost court-like setting where the women making justice claims also bear the burden of proof and can be questioned in terms of their motives and credibility. In the following news article excerpt, published in Svenska Dagbladet ( $S v D)$, accusations against Virtanen are reported as issued by several women independently of one other and wherein one particular woman's story is partly confirmed by her male friend.

"Independently of each other, they describe in detail the same foul and sexual language and invectives for women they claim the Aftonbladet journalist uses. Here is a selection of the women's stories:

In the beginning of the 00 's, Lisa is subjected to the Aftonbladetwriter on a night out in Eskilstuna, she tells SvD. Towards the end of the night, she tags along with the writer to the Stadshotellet for an after party. In the taxi is also Lisa's friend Erik, who has confirmed his presence.

Lisa describes coming along with the Aftonbladet journalist to his room, expecting others to join in." ("Tolv kvinnor anklagar Virtanen för sextrakasserier och övergrepp", Svenska Dagbladet)

Legal language is also used in the breaking news stories regarding Arnault, published in Dagens Nyheter. When no other witnesses were able to back up the women's stories, the journalist went on to interview others to provide credibility, as seen below. 
"Out of the 18 women I have interviewed, five tell stories of incidents that lack eyewitnesses. In those cases, their stories are verified by people close to the women, as well as their therapists with whom I have been in contact."

[...]

The ninth woman:

"I really wanted to work in the culture industry, and he [Arnault] approached me at an art exhibition. He was insistent afterwards and I allowed it. I felt that a job at the Club [Arnault's culture establishment in central Stockholm] would be good for my career. I went to a couple of events and at one of them, he made advances and I did not like that. When I refused, he became very aggressive. I was scared of him and it got worse when I started working at the Club. On one occasion, he forced himself on me..." ("18 kvinnor: Kulturprofil har utsatt oss för övergrepp", Dagens Nyheter)

The use of legal language achieves the goal of giving credibility to the women and their stories, but at the same time might make them susceptible to notions of doubt. Such notions are reinforced by the frequent use of modality markers such as "supposedly", as seen here: "[a]n incident supposedly occurred in the hot tub between Martin Timell and the woman..." (Oxblod, Nilsson \& Malmgren 2017-10-19), although this is arguably a way for the journalists to fulfil journalistic ethics and principles. Furthermore, the articles describe the women's various motivations to speak out about their experiences. While the idea of revenge is floated a few times in the material, the articles are centred around the idea of providing warnings and helping other women. The excerpts below illustrate how the women's motivations are portrayed.

\section{Virtanen:}

"In 2011, Cissi Wallin chose to report Fredrik Virtanen to the police, but the investigation was dropped because illegal activity could not be proven. When she published his name in connection with \#MeToo, it was not to get revenge, she says.

- I did it because I know many others do not have access to my voice, platform and 'capital'." (Cissi Wallin i unik intervju om Virtanen: Hans skydd är att vara i förnekelse, SVT Nyheter) 
Arnault:

"Many of those I have interviewed say they decided to talk about their experiences because of \#MeToo, and in order to help others. [...]

- I choose to talk about this for her sake, and for other women. In order for this to end." ("18 kvinnor: Kulturprofil har utsatt oss för övergrepp". Dagens Nyheter)

\section{Timell:}

“Decorator and TV personality Lulu Carter was the first one to sound the alarm about Martin Timell having subjected her and others at TV4 to sexual harassment and assault.” (“Lulu Carter i öppenhjärtig intervju om Martin Timell", Expressen)

Accordingly, the suggested motivations introduce a notion of female responsibility for putting a stop to the problem of sexual assault for the sake of other women. This notion of female responsibility is perhaps an extension of the idea that neoliberal discourse on female sexuality creates a female responsibility for conveying consent (Worthington 2020). However, the news media coverage focuses largely on the experiences of the victims, which might point to an effect of feminist discourse on media reports of sex crime, as suggested by several researchers (Ardovini-Brooker \& Caringella-Macdonald, 2002, Lós \& Chamard 1997, Serisier 2017). Several women victims talk about giving consent out of fear, shame and to protect their careers, indicating a move away from both narrow rape myths - where so-called "bad men" rape so-called "bad women" (Franiuk, Seefelt \& Vandello 2008, Ardovini-Brooker \& Caringella-Macdonald 2002) - and female responsibility to convey consent (Worthington 2020). Thus, as the intertextual nature of the news media coverage produces women-as-witnesses, it simultaneously challenges rape myths and introduces a new form of female responsibility. This is further reinforced through the representations of the accused men.

To establish a portrayal of Virtanen, Timell and Arnault, the various journalists conduct interviews not only with the men themselves (with the exception of Arnault), but also with acquaintances and friends of the three men. Throughout the news media coverage, these actors seem to recognise the men's behaviour as wrongful and hurt- 
ful while at the same time suggesting doubt in regard to their illegality. Thus, the men can claim victimhood by expressing innocence. Soon after being named in the press, both Virtanen and Timell give interviews. Their stories are similar in that they construct demarcations between illegal and simply "bad", "stupid” or "outdated" behaviour for which they claim some responsibility (see excerpts below). Arnault is never interviewed but is said to be "distressed" by the accusations, which, like Virtanen and Timell, he also denies, according to his defence attorney ("Kulturprofilens advokat: 'Hela hans liv har slagits i spillror", Dagens Nyheter 8 March 2018). Elsewhere in the news coverage, Arnault is described as inhabiting a "arty masculinity" (kulturmaskulinitet), having a liking for "younger women" and acting like a "gentleman" ("Kulturprofilens maktspel - hot, löften och misstänkta sexövergrepp”, Expressen 1 December 2017). Consequently, the men can deflect responsibility on the basis of demarcations between illegal and merely misogynistic behaviour. The quotes below by Virtanen and Timell reinforce this deflection of responsibility, as they both claim their behaviour has now changed for the better and that they want to apologise to the women if they got hurt by their past actions:

\section{Virtanen:}

“- I am of course very sorry if I upset people. It is disgusting and sad and I am very sorry about it.

So, you are saying this is an old behaviour, and that you are a changed person now?

- Yes, I lead a very different life today. I haven't visited a nightclub in forever and I have a family and children. At work, our jargon is sometimes harsh, crass or playful and, of course, I can't guarantee I never say anything stupid, but I do work hard to be a good person. Of course, I am sorry and want to apologise to them - I don't know who they are - if I said something inappropriate or acted improperly." ("Virtanen: Jag har betett mig tölpigt och skitstövligt", Aftonbladet)

“Timell says he meant nothing by his behaviour.

- From what I have read, I apparently touched her bottom in some breakfast queue. This is eleven years ago. I have no recollection of this, but her experience is accurate. Even if I don't remember it. Of 
course, I apologise for this as well. I have done things that I meant nothing by. It was never intended as sexual harassment." ("Martin Timell bryter tystnaden - och erkänner", Expressen)

These demarcations between both illegal and misogynistic behaviour and past behaviour and current willingness to apologise might invoke doubt in regard to the women's stories. While the articles are centred on women's experiences, which supports earlier research indicating the influence of feminist discourse has widened the concept of sex crime in news media reports beyond violent attacks by strangers (Ardovini-Brooker \& Caringella-Macdonald, 2002, Serisier 2017), their use of legal language to frame the stories presents an opportunity for the men to explain their behaviour by installing doubt about its illegality. Arguably, these explanations are present in the texts thanks to journalistic ethics and principles - according to which both sides of a story need to be heard. However, they also seem to construct notions of male victimhood. The two excerpts below indicate a male subject position of victim of unjust media coverage. While they indicate a fulfilment of journalistic principles and rightfully suggest negative personal consequences for the men being named in the media coverage, they also work to reinforce ideas of false accusations.

Timell:

“Timell calls the media coverage of him 'a witch-hunt'.

- I have been chased around the clock for four weeks. They chase me on the street. I've had to flee the country. And I have a family. How do you think it feels,' he says to SVT Nyheter." ("Martin Timell: 'Jag har fått fly landet', SVT Nyheter)

\section{Arnault:}

"How has he been affected by the allegations?

- He has suffered of course. His whole life has been more or less torn to shreds by this, which he is not the only one to experience in the aftermath of the MeToo campaign. Many have been accused in this campaign and very few allegations have been properly followed up. Those who are solely accused suffer greatly..." ("Kulturprofilens advokat: 'Hela hans liv har slagits i spillror'", Dagens Nyheter) 
Virtanen:

"Do you think you have been innocently accused and harmfully portrayed by the media?

- Yes, I do think so. I think it's a terrible thing that the internet has been a place of lynch law. We have a judicial system in this country that should handle all questions of criminal activity. I don't think one should name and shame people in social media. The accused is not allowed to defend oneself." ("Virtanen: Jag har betett mig tölpigt och skitstövligt", Aftonbladet)

As these texts invoke victimhood and doubt, they may skew the focus of the coverage toward issues of journalistic ethics and the consequences of accusations of sexual assault for the accused men. In the third excerpt above, Virtanen contrasts the media portrayal of him to a functioning judicial system. Thus, the formation of the subject position of "male victim" furthers a notion of the media coverage accusations as pitted against an objective justice system. Although the reports that initially broke the stories make use of legal language, arguably in order to provide credibility and legitimacy to the stories, both the demarcations between illegal and "bad", and suggestions of media witch hunts in the men's stories, might deflate the trustworthiness of the women. Altogether, the coverage seems to prioritise legal discourse as producer of objective truth, which might signal its hegemonic stance (Laclau \& Mouffe 1985, Chouliaraki \& Fairclough 1999). Thus, the use of legal language to produce credibility for the women witnesses might at the same time enable demarcations between illegal and simply "bad" behaviour, consequently creating notions of male victimhood as well as doubt in regard to the women's stories.

\section{Opinion pieces: Women-as-heroines and powerful men}

In the opinion pieces, the subject position of woman-as-witness is supplemented with that of woman-as-heroine. The idea - that some of the news articles seem to issue a warning and/or attempt to help other women by encouraging them to speak up and discuss their experiences - is visible here as well, but the language use is 
influenced by both literary and legal language. While the women witnesses are constructed as brave heroines showing both courage in speaking up and incurring inevitable negative consequences for attempting to stop any further abuse from the men, the men are depicted as "bad people" with power. The opinion pieces also suggest that some of the men's workplace and industry colleagues knew about their behaviour but remained silent. These depictions and subject positions are visible in the following excerpts from opinion pieces published in the tabloid newspaper Expressen (first excerpt) and the broadsheet newspaper Dagens Nyheter (second and third excerpts).

“Isabel, 26, and Amanda, 30, are my heroines. [...] It was then that Isabel, born in 1991, had to go to battle — with her body — and tell the story of its implosion at the hands of her boss, she had to take the risk and pay the price, with her name and her picture, to tell her story. [..] It was \#MeToo then, and this brave young woman had to deal with something that previous executives should have rectified earlier" ("Britta Svensson: Det är våra döttrar som har tagit striden", Expressen)

“It began with 18 women. Eighteen brave women who told stories about harassment and grave sexual misconduct by a man with ties to the 18 chairs [in the Swedish Academy], in Matilda Gustavsson's reportage in DN..." ("Björn Wiman: Att kvinnorna inte nämns är en arrogans som gränsar till skamlöshet", Dagens Nyheter)

“Man's terrifying informal power, the fear of falling into disgrace in the eyes of the Swedish Academy - those are sociologically informative explanations. But nevertheless, they are also depressing depictions of submission to real or imagined authorities. There are several reasons for this lack of moral courage. I think it is about contempt or disloyalty for the victims. The same contempt and disloyalty that victims of sex crime have been subjected to since the beginning of time, and still persist today." ("Malin Ullgren: Det är djupt provocerande att höra alla som säger att de inget visste", Dagens Nyheter) 
Although extracted from different publications, the excerpts put forward similar understandings of both the \#MeToo movement and the media coverage of it. Men with power have had the opportunity to behave badly towards women and still keep their powerful positions in part because the surrounding people involved stayed silent. This depicts sexual assault as a structural problem, a depictive frame used by Swedish media in their \#MeToo coverage to a larger extent than in other countries, as Askanius and Moller Hartley (2019) suggest. In the fall of 2017, brave women came forward and gave testimony, and as a consequence, the men lost their so-called power. While this interpretation of the \#MeToo movement may indicate demands for justice concerning all three of Fraser's $(2005,2011)$ justice dimensions: recognition (of guilt), redistribution (of power) and representation (of brave women in the concerned workplaces), it arguably reinforces the female responsibility suggested earlier in the analysis. Thus, while the problem might be depicted as structural, the solution seems to rely (although reluctantly) on individualised female responsibility, possibly supporting the notion that \#MeToo and other hashtag movements might risk reinforcing neoliberal notions of responsibility (Worthington 2020). However, the use of literary language might suggest that these opinion pieces function as arenas for alternate discourse of sexual misconduct as they depart from the constraints of legal discourse. Women-as-heroines are not subjected to notions of doubt as much as women-as-witnesses are. The opinion pieces describe the accused men as powerful and repulsive, the women victims as brave heroines and the surroundings as responsible for having protected the men. Thus, they suggest a shared responsibility for putting an end to sexual assault. Some of the texts explicitly suggest that too little responsibility has been ascribed to the men. Nonetheless, the position of woman-as-heroine subtly reinforces the idea of female responsibility and by extension constructs the problem of sexual assault as solvable only when women are brave, outspoken and able to warn others.

\section{Facebook comments: Hypocrites and doubt}

In contrast to the news articles, throughout the Facebook comments, responsibility is arguably more dispersed between actors, 
perhaps due to both fewer and less severe regulations of comment fields than of journalistic material published in news media. All three accused men are referred to with various negative monikers such as "hypocrite", "dirty old man", "sex lunatic", "a shame for the male species", shown in these comments:

"Hopefully someone will learn from this and it's a pity for all involved that dirty old men think they can do whatever they want!!!" (Comment from the article "Assistenten slog larm om sexanklagad TV4-profil: 'Jag fick högre lön för att vara tyst" about Timell, shared on Aftonbladet's Facebook page 2017-10-19)

"Get rid of him immediately. He is a shame for the male species." (Comment from the article "12 kvinnor anklagar Virtanen för sextrakasserier och övergrepp", shared on Svenska Dagbladet's Facebook page 2017-10-25)

"[I] love that all these hypocrites in the culture and media world are now getting caught for all their assaults..." (Comment from the article "Känd kulturprofil anklagas för övergrepp" about Arnault, shared on Svenska Dagbladet's Facebook page 2017-11-21)

The men are more blatantly blamed here than in the news media. However, the notions of male victimhood and female responsibility are reinforced here as well. Many comments invoke the judicial system and journalistic ethics when talking about the women and the media, which connotes distrust and doubt in regard to the accusations and reinforces the male position of victim. This, again, might skew the discussion towards focusing on the behaviour of the women-as-witnesses and their decisions to blame the men through the media, rather than the explicit behaviour of the men. In the examples below, the comments use legal discourse to question the media reports and the women.

Arnault:

"He [Arnault] is a suspect and reported to the police, but why portray him as guilty. It will be very interesting to see what will be written about him if he gets acquitted or if the case is dropped from lack of evidence. Will they still argue his guilt at all costs, or will they 
apologise and hope he won't sue them? Regardless, the journalism we can see as a result of ME TOO [sic!] is not worthy of a state governed by the rule of law. Suddenly, accusations are enough to condemn someone. It's all gone to hell." (Comment from the article "Kulturprofilens maktspel: Hot, löften och misstänkta sexövergrepp" about Arnault, shared on Expressen's Facebook page 201712-01)

"Oh, so he was named and shamed with his face and all, before any trial and conviction." (Comment from the article "Kulturprofilens maktspel: Hot, löften och misstänkta sexövergrepp" about Arnault, shared on Expressen's Facebook page 2017-12-01)

“Commenter 1: No man can get away with it any longer! \#MeToo Commenter 2: Great attitude, go ahead and abolish the legal system and instead we will introduce mob law where only those who make the most noise gets heard. And the accused are assumed guilty." (Comment from the article "12 kvinnor anklagar Virtanen för sextrakasserier och övergrepp", shared on Svenska Dagbladet's Facebook page 2017-10-25)

"I think it's wrong to name and shame someone before they are convicted!" (Comment from the article "Assistenten slog larm om sexanklagad TV4-profil: 'Jag fick högre lön för att vara tyst" about Timell, shared on Aftonbladet's Facebook page 2017-10-19)

Naming someone in the media prior to conviction is said by the commenters to pose a threat to the justice system and rule of law. As the news articles and opinion pieces discuss whether to name the men or not from the point of view of journalistic ethics, it is perhaps not surprising that the comments debate this issue as well. However, this critique forms a basis for the commenters to question the experiences by the women depicted in the press. In regard to the Virtanen and Timell cases, many Facebook comments question why the women did not report the assaults to the police at the time of the event. The comments below are examples of this:

"Why not report the crime to the police at the time, instead of several years after the fact. Well, money. Makes you wonder!!!" 
(Comment from the article "Assistenten slog larm om sexanklagad TV4-profil: 'Jag fick högre lön för att vara tyst" about Timell, shared on Aftonbladet's Facebook page 19-10-2017)

"Why so long to report? Seems like it's been going on for a long time!!!!" (Comment from the article "12 kvinnor anklagar Virtanen för sextrakasserier och övergrepp", shared on Svenska Dagbladet's Facebook page 2017-10-25)

In the case of Arnault, several comments also bring into question his wife, arguably claiming she should have been aware of Arnault's behaviour and could have possibly stopped him.

"His wife must have known about his way of life; how does she stand for this." (Comment from the article "Kulturprofilens maktspel: Hot, löften och misstänkta sexövergrepp" about Arnault, shared on Expressen's Facebook page 2017-12-01)

"Don't know who he is, but apparently he is disgusting to say the least — what does the wife say?" (Comment from the article "Kulturprofilens maktspel: Hot, löften och misstänkta sexövergrepp" about Arnault, shared on Expressen's Facebook page 2017-12-01)

Thus, these comments reinforce notions of female responsibility for ending the problem with sexual assault. When women victims do not fulfil this responsibility, their actions are depicted as questionable. This installs a sense of doubt — did the assault really happen the way she said it did - and reinforces the male subject position of victim of unjust media coverage. However, the comments provide explanations for why women may have neglected reporting the crime to the police and instead turned to the media. Several commenters suggest that the justice system provides limited possibilities in convicting sexual offenders as “it's one person's word against another's and the victim will lose, and the perpetrator can claim it didn't happen" as one person writes in the Virtanen comment field. This is visible in the exchange below:

“Commenter 1: [...]When a crime has been committed you should always report it to the police, even though the case might be drop- 
ped later. The same is true if you get set up on Blocket [a Swedish website for classified ads] and know the investigation will be dropped because if enough people report to the police, they have to act. Commenter 2: It's common that women don't report sex crimes because of how the police and the legal system treat women victims. Many say it felt like a second assault." (Comments from the article "12 kvinnor anklagar Virtanen för sextrakasserier och övergrepp", shared on Svenska Dagbladet's Facebook page 2017-10-25)

Discussions such as this might problematise the privileged position of the judicial system as the sole producer of truth. At the same time, no comment in either comment field suggests solutions to the societal problem of sexual assault outside of legal proceedings, and several comments suggest media coverage of the \#MeToo movement pose a threat to both the judicial system and the rule of law in society. The dominance of legal language and the adherence to journalistic ethics in the news articles work to limit the possibilities of understanding experiences of sexual assault prior to judicial proceedings and convictions in the Facebook comment fields. As legal discourse seems to produce hegemonic notions of sexual misconduct in the material as a whole, the need for expansion of the consent/ rape dichotomy suggested by Tosh (2016) and Thomas, Lafrance and Stelzl (2018) might also be applicable here. At the same time, many commenters agree that the men have behaved badly and that they were protected by a culture of silence in both the media and culture industries. This might suggest that the \#MeToo movement has in fact functioned as an arena for feminist discourse constructing sexual assault as a structural problem via the linking together of many heterogeneous stories, as suggested by Gill and Orgad (2018) and Clark (2016).

\section{Conclusions}

This analysis of the news media coverage of three cases of accusations of sexual assault against well-known men in the wake of the \#MeToo movement in Sweden, as well as some responses in the form of opinion articles and audience comments on Facebook, suggest legal discourse works to limit negotiations of the meaning 
of unwanted sexual attention. By producing the subject positions of women-as-witnesses, the news stories convey a sense that female responsibility alone must function as the means to end the problem of sexual assault. At the same time, the seemingly hegemonic position of legal definitions of sexual assault creates demarcations between illegal and simply "bad" behaviour which instils a sense of doubt in regard to the stories of the women. This works to produce a subject position of men-as-victims in media "witch hunts". The judicial system and journalistic ethics and principles are used to contrast a suggested unjust treatment of the accused men in the media.

Many Facebook comments depart from this when questioning the women for not reporting the events directly to the police and for instead telling their stories in the media. Although the opinion pieces deviate somewhat from legal discourse and use literary language to describe the bravery of the women who came forward in the news stories, they, possibly unintentionally, reinforce the idea of female responsibility by producing women-as-heroines. The study thus supports findings from earlier research indicating media reports on sex crime both reassure and challenge stereotypical notions of rape ("rape myths") (Ardovini-Brooker \& Caringella-Macdonald, 2002, Lós \& Chamard 1997, Serisier 2017). Notions of "real rape" are conveyed through demarcations between illegal and "bad" behaviour, but at the same time, the behaviour of the men is depicted as bad and wrong throughout the material. Thus, the analysis indicates a continuing struggle for hegemony within the discourse on sexual assault, as indicated by Worthington (2008), and there still seems to be a need of an expansion of the possibilities of negotiation beyond the restraints of legal language and principles (Tosh 2016, Thomas, Lafrance \& Stelzl 2018). Otherwise, the discussion risks focusing on how well women live up to their role of witnesses rather than focusing on the behaviour of the men, as indicated in the Facebook comments.

The study suggests that the news media coverage of the three cases focuses largely on the experiences of the women who fell victim to the assaults, which supports earlier research suggesting feminist discourse caused media reports on sex crime to concentrate on the victim's perspective (Ardovini-Brooker \& Caringella-Macdonald, 2002, 
Lós \& Chamard 1997, Serisier 2017). At the same time, the women are depicted as motivated by a need to warn and help other women, which creates a notion of female responsibility for putting an end to the problem of sexual assault. Further reinforcing this gendered responsibility are the descriptions of women-as-heroines in the opinion pieces, as well as the questioning of the actions of the victims and the wives of the accused men found in many of the Facebook comments. This supports findings from research on the \#MeToo movement and other feminist hashtag movements indicating that while such movements are successful in linking together heterogeneous stories to produce discourse on structural explanations for the problem with sexual assault, they might risk strengthening neoliberal notions of individualised female responsibility (Clark 2016, McDonald 2019, Modrek \& Chakalov 2019, Gill \& Orgad 2018, Worthington 2020).

Perhaps, as suggested by Askanius and Møller Hartley (2019), the Swedish media coverage of accusations in the wake of \#MeToo, more so than in other countries, framed the issue of sexual assault as structural. The fact that the Swedish law on sex crime was changed to include demands for consent in 2018 is in line with this finding and the analysis also indicates such structural explanations, for instance, descriptions of a "silence culture" in many interviews and opinion pieces. However, the study suggests neoliberal notions of female responsibility are reinforced not so much in demands for conveying consent but in how solutions to the structural problem of sexual assault are presented. The positive images of the witness and the heroine helping other women fortifies the idea of gendered solidarity indicated in previous research on feminist hashtag movements (Clark 2016), but might at the same time limit the \#MeToo movement by presenting outspoken women as an individual solution for the structural problem of sexual assault (De Benedictis, Orgad \& Rottenberg 2019).

Fraser's $(2005,2011)$ call for feminist movements to make justice claims on three dimensions - redistribution, recognition and representation - might provide a tool to circumvent this limitation. By adding responsibility to claims of redistribution and recognition, so that the solution to the structural problem of sexual assault is never 
dependent on individual women speaking up (to a considerable personal risk), but rather on workplaces, law makers, educators and individual men taking responsibility, the \#MeToo movement might significantly advance feminist counter-discourse in the media coverage arena of sexual assault. Recognition of notions of female responsibility on a discursive level might provide possibilities for a redistribution of the responsibility for halting sexual assault. This study has indicated that even though Swedish news media coverage of both the \#MeToo movement and its audiences' reactions make room for feminist explanations of the structural nature of sexual assault, the hegemonic stance of legal discourse limits the possibilities for a redistribution of responsibility for ending the problem. However, the sample is small and limited in both time span and scope, which leaves much room for future research. Such studies might examine the prevalence of counter-discourse and notions of female responsibility in other parts of the media coverage of \#MeToo in Sweden and elsewhere, as well as in self-published experiences of sexual assault in social media. User ethnography would provide an important perspective on how social media users relate to hashtag movements when participating in the debate or in the movement itself.

\section{REFERENCES}

Aftonbladet. (2018). Official Facebook Page: "Våra regler”. facebook.com/pg/ aftonbladet/about/. Retrieved April 20, 2020.

Ardovini-Brooker, J. \& Caringella-MacDonald, S. (2002). Media Attributions of Blame and Sympathy in Ten Rape Cases. The Justice Professional, 15(1), 3-18. https://doi.org/10.1080/08884310212826

Askanius, T. \& Møller Hartley, J. (2019). Framing Gender Justice. A Comparative Analysis of the Media Coverage of \#MeToo in Denmark and Sweden. Nordicom Review, 40(2), 19-36. https://doi.org/10.2478/nor-2019-0022

Barker-Plummer, B. \& Barker-Plummer, D. (2017). Hashtag Feminism, Digital Media, and New Dynamics of Social Change: A Case Study of \#YesAlIWomen. In G. W. Richardson (Ed.), Social Media and Politics: A New Way to Participate in the Political Process, vol 2. (pp. 79-96). Praeger.

Chouliaraki, L. \& Fairclough, N. (1999). Discourse in Late Modernity: Rethinking Critical Discourse Analysis. Edinburgh University Press.

Clark, R. (2016). 'Hope in a Hashtag': The Discursive Activism of \#WhyIStayed. Feminist Media Studies, 16(5), 788-804. https://doi.org/10.1080 
/14680777.2016.1138235

Dagens Nyheter. (2018). Official Facebook Page: "Policy för kommentarer". facebook.com/pg/dn.se/about/. Retrieved April 20, 2020.

De Benedictis, S., Orgad, S. \& Rottenberg, C. (2019). \#MeToo, Popular Feminism and the News: A Content Analysis of UK Newspaper Coverage. European Journal of Cultural Studies, 22 (5-6), 718-738. https://doi. org/10.1177/1367549419856831

Expressen. (2020). Official Facebook Page: “Our Story”. facebook.com/pg/ expressen/about/. Retrieved April 20, 2020.

Franiuk, R., Seefelt, J. L. \& Vandello, J. A. (2008). Prevalence of Rape Myths in Headlines and Their Effects on Attitudes Toward Rape. Sex Roles, 58, 790-801. https://doi.org/10.1007/s11199-007-9372-4

Fraser, N. (2003). Den radikala fantasin. Mellan omfördelning och erkännande. Daidalos $\mathrm{AB}$.

Fraser, N. (2005). Mapping the Feminist Imagination: From Redistribution to Recognition to Representation. Constellations, 12(3), 295-307. https://doi. org/10.1111/j.1351-0487.2005.00418.x

Fraser, N. (2011). Rättvisans mått: Texter om erkännande, omfördelning och representation i en globaliserad värld (Red. Lindgren, J.). Bokförlaget Atlas.

Freeman, J. (1993). The Disciplinary Function of Rape's Representation: Lessons from the Kennedy Smith and Tyson Trials. Law \& Social Inquiry, 18(3), 517-546. https://doi.org/10.1111/j.1747-4469.1993.tb00667.x

Gill, R. \& Orgad, S. (2018). The shifting terrain of sex and power: From the 'sexualization of culture' to \#MeToo. Sexualities, 21(8), 1313-1324. https:// doi.org/10.1177/1363460718794647

Hamlin, J. E. (1988). Who's the Victim? Women, Control and Consciousness. Women's International Studies Forum, 2(3), 223-233. https://doi. org/10.1016/0277-5395(88)90137-9

Hinck, S.S. \& Thomas, R. W. (1999). Rape Myth Acceptance in College Students: How Far Have We Come? Sex Roles, 40(9/10), 815-832. https://doi. org/10.1023/A:1018816920168

Internetstiftelsen. (2019). Svenskarna och internet 2019. svenskarnaochinternet.se/rapporter/svenskarna-och-internet-2019/. Retrieved April 20, 2020.

Johnson, Michelle. (1999). How Identifying Rape Victim Affects Readers' Perceptions. Newspaper Research Journal, 20(2), 64-80. https://doi. org/10.1177/073953299902000206

Laclau, E. \& Mouffe, C. (1985). Hegemony and Socialist Strategy.Verso.

Lonsway, Kimberly A. \& Fitzgerald, Louise F. (1994). Rape Myths: In review. 
Psychology of Women Quarterly, 18, 133-164. https://doi.org/ 10.1111/ j.1471-6402.1994.tb00448.x

Lós, M. \& Chamard, S. E. (1997). Selling Newspapers or Educating the Public? Sexual Violence in the Media. Canadian Journal of Criminology, 293328. https://doi.org/10.3138/cjcrim.39.3.293

McDonald, A. F. (2019). Framing \#MeToo: Assessing the Power and Unintended Consequences of a Social Media Movement to Address Sexual Assault. In W. T. O’Donohue \& P.A. Schewe (Eds.). Handbook of Sexual Assault and Sexual Assault Prevention. Springer.

Meyers, M. (1997). News Coverage of Violence against Women: Engendering Blame. Sage Publications.

Modrek, S. \& Chakalov, B. (2019). The \#MeToo Movement in the United States: Text Analysis of Early Twitter Conversations. Journal of Medical Internet Research, 21(9), 1-15. https://doi.org/10.2196/13837

Schneider, K. T. \& Carpenter, N. J. (2020). Sharing \#MeToo on Twitter: Incidents, Coping Responses, and Social Reactions. Equality, Diversity and Inclusion: An International Journal, 39(1), 87-100. https://doi. org/10.1108/EDI-09-2018-0161

Serisier, T. (2017). Speaking out, and Beginning to be Heard: Feminism, Survivor Narratives and Representations of Rape in the 1980s. Continuum, 32(1), 52-6. https://doi.org/10.1080/10304312.2018.1404675

Statens medieråd. (2020). "Fakta: Etiska regler för medieproducenter". statensmedierad.se/larommedier/juridikochmedier/faktaetiskareglerformedieproducenter. Retrieved April 20, 2020.

Svenska Dagbladet. (2016). “SvD:s regler för kommentering”. https://www. svd.se/svds-regler-for-kommentering. Retrieved April 20, 2020.

Thomas, E. J., Lafrance, M. N. \& Stelzl, M. (2018). Mis/Representation and the Media: A Reflection on Experiences with Media Engagement. Sexualities, 21(4), 692-696. https://doi.org/10.1177/1363460717708148

Tosh, J. (2016). Celebrity 'Rape-Rape': An Analysis of Feminist and Media Definitions of Sexual Violence. Psychology of Women Section Review, 18(1), 27-42.

Winther Jørgensen, M. \& Phillips, L. (2002). Discourse Analysis as Theory and Method. Sage.

Worthington, N. (2020). Celebrity-Bashing or \#MeToo Contribution? New York Times Online Readers Debate the Boundaries of Hashtag Feminism. The Communication Review, 23 (1), 46-65. https://doi.org//10.1080/1071 4421.2019.1704110

Worthington, N. (2008). Encoding and Decoding Rape News: How Progressive 
Reporting Inverts Textual Orientations. Women's Studies in Communication, 31(3), 344-367. https://doi.org/10.1080/07491409.2008.10162546

\section{MATERIAL: ARTICLES AND COMMENT FIELDS}

The Case of Fredrik Virtanen:

Karén, F. (2017). "Fredric Karén: Därför publicerar SvD Fredrik Virtanens namn", Svenska Dagbladet 2017-10-25, https://www.svd.se/darfor-publicerar-svd-fredrik-virtanens-namn

Lapidus, A. (2017). "Virtanen anklagas för sexövergrepp”, Expressen 201710-25, https://www.expressen.se/nyheter/fredrik-virtanen-anklagas-forsexovergrepp/

Mokthari, A. (2017). “Cissi Wallin i unik intervju om Virtanen: Hans skydd är att vara i förnekelse., SVT Nyheter 2017-10-25, https://www.svt.se/nyheter/inrikes/cissi-wallin-i-unik-intervju-om-virtanen-hans-skydd-ar-attvara-i-fornekelse

Nordberg, J. (2017). “Advokat: 'Allvarligt med arbetsgivarens tystnadskultur"', Svenska Dagbladet 2017-10-25, https://www.svd.se/advokaten-arbetsgivarens-tystnadskultur-ser-jag-som-mycket-allvarligt

Pettersson, K. (2017). “Om krisen på Aftonbladet”, Aftonbladet 2017-10-29, https://www.aftonbladet.se/ledare/a/Lye7p/om-krisen-pa-aftonbladet

Sundkvist, F. \& Nordberg, J. (2017). "12 kvinnor anklagar Aftonbladetprofil för sextrakasserier och övergrepp”, Svenska Dagbladet 2017-10-25, https://www.svd.se/12-kvinnor-anklagar-aftonbladetprofil-for-sextrakasserier-och-overgrepp

Thornéus, E. (2017). "Virtanen: Jag har betett mig tölpigt och skitstövligt", Aftonbladet 2017-10-25, https://www.aftonbladet.se/nyheter/a/GvO8m/ virtanen-jag-har-betett-mig-tolpigt-och-skitstovligt

\section{Facebook Comment Field:}

Svenska Dagbladet on Facebook. (2017). "Han var Fredrik Virtanen. Jag var ingen'. SvD har granskat redogörelser från kvinnor från ett helt decennium.", 2017-10-25, https://www.facebook.com/svenskadagbladet/ posts $/ 10154832892496174$ ?_tn__ $=-\mathrm{R}$.

The Case of Martin Timell:

Hagen, C. (2017). “Hur länge har han varit omskvallrad?”, Expressen 2017-1026, https://www.expressen.se/kronikorer/cecilia-hagen/hur-lange-harhan-varit-omskvallrad/

Lindkvist, H. \& Aretakis, L. (2017). "Anna Hedenmo: 'Pinsamt att bli outad som tafsande gubbe”, Dagens Nyheter 2017-10-24, https://www.dn.se/ 
kultur-noje/anna-hedenmo-pinsamt-att-bli-outad-som-tafsandegubbe/

Ohlin, J. (2017). “Martin Timell: 'Jag har fått fly landet”', SVT Nyheter 201711-12, https://www.svt.se/nyheter/inrikes/martin-timell-jag-har-fatt-flylandet

Oxblod, A., Thomsen, D., Sohl Stjernberg, M. \& Nilsson, A. (2017). “Anklagelserna mot TV4- stjärnan Martin Timell”, Expressen 2017-10-18, https:// www.expressen.se/noje/anklagelserna-mot-tv4-stjarnan-martin-timell/

Oxblod, A., Nilsson, A. \& Malmgren, K. (2017). “Timell kränkte kvinnlig assistent i badtunna - nu tas han ur tjänst”, Expressen 2017-10-19, https:// www.expressen.se/noje/timell-krankte-kvinnlig-assistent-i-badtunna-/

Oxblod, A. \& Nilsson, A. (2017). “Tv-profilen: Timell visade mig sitt kön”, Expressen 2017-10-21, https://www.expressen.se/noje/tv-profilen-timellvisade-mig-sitt-kon-/. Visited 30 January 2020

Roos, M. (2017). "Martin Timell bryter tystnaden - och erkänner", Expressen 2017-10-20, available at: https://www.expressen.se/noje/martin-timellbryter-tystnaden-och-erkanner-/

Sköld, J. \& Kullving, C.-J. (2017). “Jag tror att det är ett undantag, ett rötägg”, Dagens Nyheter 2017-10-24, https://www.dn.se/arkiv/nyheter/jag-troratt-det-ar-ett-undantag-ett-rotagg/

Trus, H., Pettersson, L. \& Dickson, S. (2017). “Tv-profilen: De visste om allt men blundade för det", Aftonbladet 2017-10-19, https://www.aftonbladet. se/nojesbladet/a/W4lEG/tv-profilen-de-visste-om-allt-men-blundadefor-det

Trus, H. \& Pettersson, L. \& Forsberg, O. (2017). "Assistenten: De betalade för min tystnad", Aftonbladet 2017-10-19, https://www.aftonbladet.se/ nojesbladet/a/3Lknv/assistenten-de-betalade-for-min-tystnad

Westin, A., Trus, H. \& Bustamante, S. (2017). "Lulu Carter i öppenhjärtig intervju om Martin Timell", Aftonbladet 2017-10-20, https://www.aftonbladet.se/nojesbladet/a/nkwkm/lulu-carter-i-oppenhjartig-intervjuom-martin-timell

Facebook Comment Field:

Aftonbladet on Facebook. (2017). "Den folkkära TV4-profilen ska ha stoppat sin hand innanför hennes bikinitrosor på jobbfesten, inför deras kollegor. $\mathrm{Nu}$ berättar hon.", 2017-10-19: https://www.facebook.com/aftonbladet/ posts/1793497313993796?_tn__=-R

The Case of Jean Claude Arnault:

Andersson, A. (2017). "Arnault flydde landet efter anklagelserna”, Expressen 2017-12-16, https://www.expressen.se/nyheter/arnault-flydde-landet- 
efter-overgreppsanklagelserna/

Berg, A. (2017). "Vi kan inte blocka allt som osar ondska”, Dagens Nyheter 2017-11-30, https://www.dn.se/kultur-noje/aase-berg-vi-kan-inteblocka-allt-som-osar-ondska/

Gustavsson, M. (2017). “18 kvinnor: Kulturprofil har utsatt oss för övergrepp”, Dagens Nyheter 2017-11-21, https://www.dn.se/kultur-noje/18-kvinnorkulturprofil-har-utsatt-oss-for-overgrepp/.

Hakelius, J. (2017). “Har kulturprofilen inget förhållande till romantik?", Expressen 2017-11- 25, https://www.expressen.se/kronikorer/johanhakelius/har-kulturprofilen-inget-forhallande-till-romantik-/

Kärde, R. (2017). "Pratet om tystnadskultur urholkar frågan om ansvar", Dagens Nyheter 2017- 11-28, https://www.dn.se/kultur-noje/rebeckakarde-pratet-om-tystnadskultur-urholkar-fragan-om-ansvar/

Lapidus, A. (2017). "Så utnyttjade kulturprofilen sin makt för sextrakasserier", Expressen 2017-11-26, https://www.expressen.se/noje/sa-utnyttjade-kulturprofilen-sin-makt-for-sextrakasserier/

Lapidus, A., Andersson, A., Jakobson, H. \& Baas, D. (2017). “Kulturprofilens maktspel - hot, löften och misstänkta sexövergrepp", Expressen 2017-1201, https://www.expressen.se/nyheter/kulturprofilens-maktspel--hotloften-och-misstankta-sexovergrepp/

Lindkvist, H. (2018). "Kulturprofilens advokat: 'Hela hans liv har slagits i spillror"', Dagens Nyheter 2018-03-08, https://www.dn.se/kultur-noje/ kulturprofilens-advokat-hela-hans-liv-har-slagits-i-spillror/

Svensson, B. (2017). "Det är våra döttrar som har tagit striden", Expressen 2017-11-23, https://www.expressen.se/kronikorer/britta-svensson/detar-vara-dottrar-som-har-tagit-striden/

Ullgren, M. (2017). “Det är djupt provocerande att höra alla som säger att de inget visste”, Dagens Nyheter 2017-11-24, https://www.dn.se/kultur-noje/ malin-ullgren-det-ar-djupt-provocerande-att-hora-alla-som-sager-attde-inget-visste/

Wiman, B. (2017). "Att kvinnorna inte nämns är en arrogans som gränsar till skamlöshet”, Dagens Nyheter 2017-12-21, https://www.dn.se/arkiv/kultur/bjorn-wiman-att-kvinnorna-inte-namns-ar-en-arrogans-som-gransar-till-skamloshet/

Facebook Comment Fields:

Expressen on Facebook. (2017). “Trots sexavslöjande 1997 fortsatte Svenska Akademien attstödjaJean-ClaudeArnault-nuharfemkvinnorpolisanmält 'kulturprofilen' för sexuella trakasserier och övergrepp.,' 2017-12-01, https://www.facebook.com/expressen/posts/10155378562935345? 


$$
\mathrm{tn}
$$

Svenska Dagbladet on Facebook. (2017). “18 kvinnor anklagar i DN en känd profil i kulturvärlden för sexuella trakasserier och övergrepp. Mannen har nära band till Svenska Akademien, och flera av händelserna ska enligt DN ha ägt rum i lägenheter som ägs av Akademien", 2017-11-21, https://www. facebook.com/svenskadagbladet/posts/10154893993751174?_tn__=-R

\section{LISA LINDOVIST}

PhD Student

Department of Social and Psychological Studies Karlstad University

Universitetsgatan 2, 65188 Karlstad, Sverige

lisa.lindqvist@kau.se

\section{HILLEVI GANETZ}

Professor

Dept. of Ethnology, History of Religions and Gender Studies Stockholm University Frescativägen, 11419 Stockholm, Sverige hillevi.ganetz@gender.su.se 